\title{
IQ LEVEL, EDUCATION AND ECONOMIC WELLBEING
}

\author{
Adina Viorica RUS ${ }^{\text {** }}$ \\ a) Babeș-Bolyai University, Faculty of Economics and Business Administration, \\ Cluj-Napoca, Romania
}

Please cite this article as:

Article History:

Rus, A.V., 2018. IQ level, education and economic

Received: 5 October 2018 wellbeing. Review of Economic Studies and Research Accepted: 14 November 2018 Virgil Madgearu, 11(2), pp.109-118.

doi: 10.24193/RVM.2018.11.29.

\begin{abstract}
The present paper proposes an analysis of the behavioral factors relevant to economic growth and is based on the study of the relationship between the traditional economy and the behavioral economy. In this paper are presented different studies on some behavioral factors and how they have influenced macroeconomics and some recommendations for developing more effective policies to take these into account. Thus, it has been shown that there is a link between the level of intelligence, IQ, education and the welfare of a nation. This was an expected outcome as they contribute to increasing productivity and technical progress, fundamental elements for economic growth.
\end{abstract}

Key words: economic welfare; GDP; IQ level education JEL Classification: $D 60 ; D 90$

(C) 2018 Alma Mater Publishing House. All rights reserved.

* Corresponding author. E-mail address: adina.rus@econ.ubbcluj.ro. 


\section{References:}

1. Akerlof, G.A. and Shiller, R.J., 2010. Spirite animale: despre felul în care psihologia umană influențează economia și ce înseamna asta pentru capitalismul global. București: Publica.

2. Dragoescu, R.M., 2015. Education as a determinant of the economic growth. The case of Romania. București: The Bucharest University of Economic Studies.

3. Frey, B., 2008. Happiness, a revolution in economics. Cambridge: The MIT Press.

4. Hafer, R.W., 2017. New estimates on the relationship between IQ, economic growth and welfare. Intelligence, 61, pp.92-101.

5. Jones, C. and Klenow, P.J., 2016. Beyond GDP? Welfare across countries and time. American Economic Review, 106, pp.2424-57.

6. Lyn, R. and Vanhanen, T., 2002. IQ and the wealth of nations. Conneticut: Westport.

7. Mankiw, G.N., 2013. Macroeconomics, $9^{\text {th }}$ edition. New York: Worth Publisher.

8. Meisenberg, G., 2004. Talent, character and the dimensions of national culture. Mankind Quarterly, 45, pp.123-69.

9. Popa, D., 2010. www.hymerion.ro. [Interactiv] Available at: http:// hymerion.ro/2010/o8/31/cateva-paradoxuri-economice-si-modulin-care-romania-se-regaseste-in-ele.html [Accessed 0103 2018]. 